\title{
Hairy Vetch Becomes an Alternative Basal N Fertilizer in Low-input Fresh- market Tomato Production in a Plastic High Tunnel
}

\author{
Rafael Alexandre Muchanga ${ }^{1}$, Toshiyuki Hirata ${ }^{2}$ and Hajime Araki ${ }^{2 *}$ \\ ${ }^{1}$ Graduate School of Environmental Science, Hokkaido University, Sapporo 060-0810, Japan \\ ${ }^{2}$ Field Science Center for Northern Biosphere, Hokkaido University, Sapporo 060-0811, Japan
}

In order to establish a low-input alternative production system based on cover crops, the effectiveness of hairy vetch (Vicia villosa Roth; HV) incorporated as a basal nitrogen fertilizer and its effects on soil carbon (C) and nitrogen $(\mathrm{N})$ content in fresh-market tomato production in plastic high tunnel was investigated in Sapporo (snow cover region), Japan. The treatments consisted of $\mathrm{HV}$ seeding rates $(\mathrm{HV} 2,2 \mathrm{~kg} / 10 \mathrm{a} ; \mathrm{HV} 5,5 \mathrm{~kg} / 10 \mathrm{a})$ and ammonium sulfate (AS10, $10 \mathrm{~kg} \mathrm{~N} / 10$ a) applied as basal $\mathrm{N}$ fertilizers, and the Non HV (control) with no HV and ammonium sulfate. In all plots, $15 \mathrm{~kg} \mathrm{~N} / 10$ a were added before tomato transplanting as a controlledrelease fertilizer (LPS100 41\%-N) to maintain the tomato growth in the mid and late stages. HV aboveground biomass (dry weight) was $585 \mathrm{~kg} / 10 \mathrm{a}$ in HV2 and $719 \mathrm{~kg} / 10 \mathrm{a}$ in HV5. Nitrate in petiole sap was higher in HV2, HV5, and AS10 plots than in Non HV plots throughout the cultivation period with the exception of the first 2 weeks after transplanting (WAT). The Growth index (GI) was higher in HV2 (47971), HV5 (46285), and AS10 (43397) than in Non HV (39847) at 7 WAT, the beginning of the harvest. Higher marketable yields were found in tomatoes grown in HV2 (6.87 t/10 a), HV5 (6.91 t/10 a), and AS10 (6.08 t/10 a), compared with the Non HV $(5.19 \mathrm{t} / 10$ a). The HV plots had greater soil total and organic $\mathrm{N}$ than AS10 and Non HV, and slightly increased soil $\mathrm{C}$ after tomato production. From these results, the $\mathrm{HV}$ seeding rate of $2 \mathrm{~kg} / 10$ a will be enough to support the growth of tomatoes planted after $\mathrm{HV}$ production if $\mathrm{HV}$ grows steadily in a plastic high tunnel.

Key Words: soil carbon, soil nitrogen, tomato yield, vegetative growth.

\section{Introduction}

Chemical fertilizers have been massively used in conventional fresh-market tomato production systems to obtain high yields. For instance, more than $200 \mathrm{~kg}$. $\mathrm{ha}^{-1}$ of $\mathrm{N}$ fertilizer have been recommended for freshmarket tomato production in Hokkaido (Association of agriculture improvement and extension, 2015), and in other districts of Japan such as Chiba, where a fertilizer rate of $310 \mathrm{~kg} \mathrm{~N} \cdot \mathrm{ha}^{-1}$ has been recommended (Tanaka, 2003). Consequently, some problems such as salt accumulation occur and excessive nitrate is prone to leach and contaminate groundwater (Meisinger et al., 1991). However, concerns about reducing environmental problems, as well as the rising demand for vegetables produced with less chemical fertilizers and pesticides have become major driving forces for the development of sustainable production systems. In Japan, reduced $\mathrm{N}$

Received; May 25, 2016. Accepted; February 3, 2017.

First Published Online in J-STAGE on April 18, 2017.

* Corresponding author (E-mail: araki@fsc.hokudai.ac.jp). input systems have been established for environmental conservation, though these systems are reliant on chemical fertilizers. Therefore, development of low-input alternative production systems based on cover crops which have more benefits beyond yield improvement, such as improvements in environmental conditions and soil quality is of great importance.

Planting cover crops before or between cash crops can improve soil properties, thereby leading to improved soil health and yield of cash crops (Araki and Ito, 1999; Hargrove, 1986; Kuo and Jellum, 2002; Kuo et al., 1997a). As a cover crop, hairy vetch (HV) serves to fix nitrogen, recycle nutrients, reduce soil erosion and compaction, and add organic matter into the soil (Abdul-Baki and Teasdale, 2007). Tomato yield and vegetative growth were greater in $\mathrm{HV}$-incorporated and mulched fields, especially in HV-mulched fields, than in no-HV fields. A large amount of supplemental $\mathrm{N}$ fertilizer did not show a positive effect on tomato yield in HV fields (Horimoto et al., 2002). Likewise, the yield of tomato in pots with $\mathrm{HV}$ and reduced supplemental $\mathrm{N}$ fertilizer (NOHV and $\mathrm{N} 80 \mathrm{HV}, 80 \mathrm{~kg} \mathrm{~N} \cdot \mathrm{ha}^{-1}$ ) was com- 
parable to that in pots with the full amount of recommended N fertilizer (N240, $240 \mathrm{~kg} \mathrm{~N} \cdot \mathrm{ha}^{-1}$ ) (Sugihara et al., 2013). Hairy vetch produces a large biomass rich in $\mathrm{N}$ and $\mathrm{C}$ which decompose and release high amounts of $\mathrm{N}$ into soil-tomato plant systems. When HV residues are incorporated in soil, a large amount of $\mathrm{N}$ derived from the residues (HV-N) is effectively absorbed by tomato plants within the first four weeks after transplanting (Sugihara et al., 2013). However, tomatoes are known to take up $\mathrm{N}$ continuously throughout the growth period (Ito et al., 1990). Thus, for sustainable tomato production using $\mathrm{HV}$, additional $\mathrm{N}$ is required for tomato growth four weeks after transplanting. The controlled-release fertilizers such as polyolefin-coated urea S-type (LPS100) may play an important role in these systems because of their delayed and continuous $\mathrm{N}$ release over the whole growing season of many vegetable crops. The use of controlled-release fertilizers results in labor cost reduction with a single basal application, higher $\mathrm{N}$ use efficiency, and reduction in nitrate pollution (Acquaye and Inubushi, 2004; Shoji and Kanno, 1994; Shoji et al., 1991). Therefore, a combination of $\mathrm{HV}$ and controlled-release fertilizer is seen to be a suitable management practice in low-input systems.

There are very limited studies on the impact of $\mathrm{HV}$ in tomato production in plastic high tunnels. The results from outdoor tomato production with HV (Abdul-Baki et al., 1997; Horimoto et al., 2002; Kumar et al., 2005; $\mathrm{Lu}$ et al., 2000) indicated positive effects of $\mathrm{HV}$ on growth and yield of tomatoes, and the results from pot examination using $\mathrm{HV}$-incorporated highlighted the possibility of $\mathrm{N}$ input reduction with the use of $\mathrm{HV}$ (Sugihara et al., 2013). The reduction of $\mathrm{N}$ fertilizer input is very important for sustainable tomato production, whereas the positive results reported previously were not obtained in field conditions, which are more complex and variable than pot soil. Additionally, the effects of $\mathrm{HV}$-incorporated on soil $\mathrm{C}$ and $\mathrm{N}$ were not investigated. The research hypotheses were: a) the incorporation of $\mathrm{HV}$ may promote vigorous growth, especially in the early growth stages, high yield and increased soil carbon and nitrogen; b) the positive effects of $\mathrm{HV}$ on tomatoes will be higher or similar to those of ammonium sulfate used in conventional systems. The present study was conducted to evaluate the effectiveness of $\mathrm{HV}$-incorporated as a basal $\mathrm{N}$ fertilizer and its effects on soil $\mathrm{C}$ and $\mathrm{N}$ in tomato production under plastic high tunnel conditions.

\section{Materials and Methods}

\section{Site and experimental design}

The experiment was conducted at the Experimental Farm, Field Science Center for Northern Biosphere, Hokkaido University, Sapporo (snow cover region), Japan, from March to October 2015 (Table 1). The soil of the site is Andisol with a clay loam texture, and its chemical composition was as follows: $3.14 \mathrm{mg} \mathrm{NO}_{3}{ }^{-} \mathrm{N}$, $0.84 \mathrm{mg} \mathrm{NH}_{4}{ }^{+} \mathrm{N}, 42.9 \mathrm{mg} \mathrm{K}{ }_{2} \mathrm{O}, 204 \mathrm{mg} \mathrm{CaO}, 60.5 \mathrm{mg}$ $\mathrm{MgO}$, and $12.7 \mathrm{mg} \mathrm{P}_{2} \mathrm{O}_{5}$ (Truog-L method) per $100 \mathrm{~g}$ dry soil taken at $0-15 \mathrm{~cm}$ depth before the examination. Soil $\mathrm{pH}$ (water, 1:2.5) and EC (1:5) were 5.8 and $42.1 \mathrm{mS} \cdot \mathrm{m}^{-1}$, respectively. The treatments consisted of two HV seeding rates, $\mathrm{HV}$ sowed at $5 \mathrm{~kg} / 10$ a (HV5) and $2 \mathrm{~kg} / 10 \mathrm{a}$ (HV2); ammonium sulfate fertilizer applied as basal $\mathrm{N}$ at a rate of $10 \mathrm{~kg} \mathrm{~N} / 10 \mathrm{a}(\mathrm{AS} 10)$ and Non HV (control; no ammonium sulfate or HV residues was applied in it). Additionally, controlled-release N fertilizer (LPS100 41\%-N; JCAM AGRI. Co., Ltd., Tokyo, Japan) was added in all plots at rate of $15 \mathrm{~kg} \mathrm{~N} /$ 10 a before tomato transplanting to supply $\mathrm{N}$ and maintain tomato growth in the mid and late stages. The LPS100 fertilizer is a 30 to 40-day delayed-release in water at $25^{\circ} \mathrm{C}$, and then 100 days release of $80 \%$ of its total $\mathrm{N}$, following a sigmoid pattern (Acquaye and Inubushi, 2004; Shoji and Kanno, 1994). The treatments were arranged in a randomized block design in three replicates.

\section{Field preparation and chemical fertilizer application}

Soil was tilled by a rotary cultivator and then the beds were raised on March 23 in 2015. The beds were

Table 1. Field operations carried out from March to October in 2015.

\begin{tabular}{ll}
\hline \hline \multicolumn{1}{c}{ Month/Date } & \multicolumn{1}{c}{ Operations } \\
\hline March 12 & Sowing of tomato rootstock and scion cultivars \\
March 24 & Sowing of HV \\
April 16 & Grafting of tomato seedlings \\
May 29 & Mowing, measurement of biomass, and chopping of HV \\
May 30 & Incorporation of HV and chemical fertilizers \\
June 1 & Transplanting of tomato seedlings \\
June 15-August 10 & Measurement of nitrate in petiole sap every 2 weeks \\
June 15-August 24 & Measurement of inorganic N every 2 weeks \\
June 22-August 17 & Measurement of the tomato growth index every 2 weeks \\
July 20-September 25 & Tomato harvesting every 2-3 days \\
October 9 & Measurement of soil C and N content \\
\hline
\end{tabular}


spaced $1.5 \mathrm{~m}$ center to center and the experimental elementary plot size was $2.4 \mathrm{~m}^{2}(3.0 \mathrm{~m} \times 0.8 \mathrm{~m})$. Hairy vetch ('Mamesuke', non-overwintering cultivar; Snow Brand Seed Co., Ltd., Hokkaido, Japan) was manually sown and superficially buried just after formation of beds on March 24. The soil in Non HV and AS10 plots was left bare throughout the HV growing period; spontaneous weeds were removed by hand. HV was irrigated as needed by hand using an irrigation tube. When HV was at the flowering stage (Fig. 1), on May 29, the whole aboveground biomass was mowed $2-3 \mathrm{~cm}$ above soil surface by hand. Soon after, the HV biomass was weighed, and then chopped into small pieces (about $10 \mathrm{~cm}$ length) for easy incorporation into the soil.

Chemical fertilizers were applied and incorporated with HV residues on May 30. Ammonium sulfate (21\% $-\mathrm{N}$ ) was applied only in AS10 plots, and $20 \mathrm{~kg} / 10 \mathrm{a}$ of $\mathrm{P}_{2} \mathrm{O}_{5}$ as fused magnesium phosphate and $20 \mathrm{~kg} / 10 \mathrm{a}$ of $\mathrm{K}_{2} \mathrm{O}$ as potassium sulfate were added in all plots.

\section{Tomato cultivation}

The seeds of the fresh-market cultivar 'Reika' and rootstock cultivar 'Friendship' were sown in sowing boxes on March 12, and seedlings were grafted using a tube grafting method on April 16. Grafted seedlings were transferred into plastic pots of $12 \mathrm{~cm}$ diameter. About two-month-old tomato seedlings were transplanted in plots on June 1 when the florets in the first cluster begin to bloom. Each plot contained 12 plants of which 8 in the core site were experimental plants and two in each edge were border plants. The planting density was 2667 plants $/ 10$ a with $0.5 \mathrm{~m}$ between tomato lines and $0.5 \mathrm{~m}$ between plants. After tomato transplanting, drip irrigation was installed to water the tomatoes; irrigation was carried out 2-3 times a week and was finished on September 25 after the last harvesting. For trellising of tomato plants, a hanging-string system was established at 2 weeks after transplanting (WAT). Lateral shoots were removed as they appeared allowing only the main shoot to grow and pollination occurred natu- rally. Fruits were collected from 1 to 8 clusters, and only four fruits were allowed to set in each cluster. Pesticides were applied 2 times to prevent sucking pest infestation and to control fruit worms and late blight. Weeds were removed by hand.

\section{Aboveground biomass, carbon, and nitrogen content of hairy vetch}

Aboveground biomass yield of HV (fresh weight) was determined just after mowing, using a total plot area, $2.4 \mathrm{~m}^{2}$. Soon after, HV residues were collected and oven dried at $60^{\circ} \mathrm{C}$ until a constant weight in order to determine their dry weight, and the $\mathrm{C}$ and $\mathrm{N}$ contents were determined by means of an elemental analyzer (Vario EL III; Elementar, Hanau, Germany). The dried residues were ground finely, and $10 \mathrm{mg}$ was weighed in Sn-foil capsules for analyses using three samples in each treatment.

\section{Soil carbon, nitrogen, and temperature}

In order to investigate the effects of $\mathrm{HV}$ and chemical fertilizer on soil inorganic nitrogen and soil total $\mathrm{C}$ and $\mathrm{N}$, soil was collected from $0-15 \mathrm{~cm}$ depth at three points in each plot and then well mixed. As a result, one sample was prepared in each plot and three samples were collected from each treatment. The soil samples were dried at room temperature, and sieved with $2 \mathrm{~mm}$ mesh. Soil inorganic nitrogen $\left(\mathrm{NO}_{3}^{-}-\mathrm{N}+\mathrm{NH}_{4}^{+}-\mathrm{N}\right)$ was measured by using a soil analyzer (ZA-II Zen-noh; National Federation of Agricultural Cooperative Associations, Tokyo, Japan). $\mathrm{NO}_{3}{ }^{-} \mathrm{N}$ and $\mathrm{NH}_{4}{ }^{+}-\mathrm{N}$ were measured by the alkali reduction-diazotization and indophenol methods, respectively. The soil total $\mathrm{C}$ and $\mathrm{N}$ were determined using an elemental analyzer (Vario EL III; Elementar). $20 \mathrm{mg}$ of minced dry soil were weighed in Sn-foil capsules and then analyzed. Organic nitrogen was calculated as follows: Organic nitrogen $=$ total nitrogen - inorganic nitrogen. The soil samples for inorganic nitrogen analyses were collected 7 times, at 0 , $2,4,6,8,10$, and 12 WAT, while the samples for total C
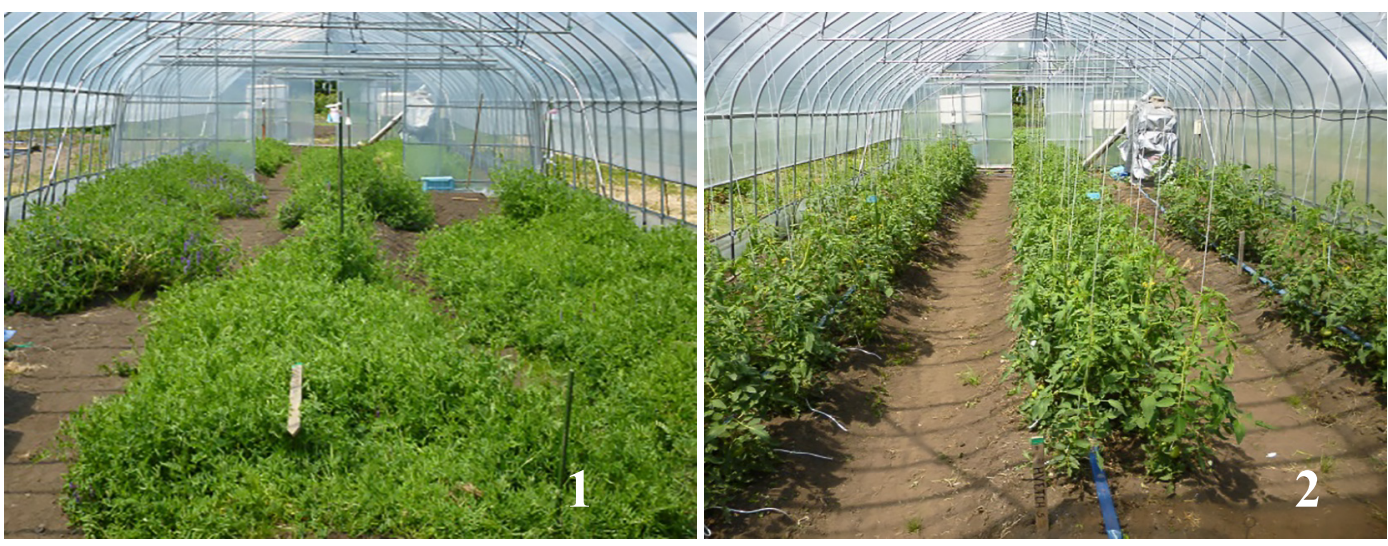

Fig. 1. Hairy vetch growing in the plastic high tunnel, May 29 in 2015 (1); and tomatoes growing in bare and HV plots in the plastic high tunnel, June 29 in 2015 (2). 
and $\mathrm{N}$ analyses were collected before and after tomato cultivation.

Soil and air temperatures of the plastic high tunnel were measured and recorded with the aid of a data logger (midi Logger GL800; Graphtec Co., Yokohama, Japan) every hour from the establishment of HV until the end of tomato cultivation. Three sensors were set at $15 \mathrm{~cm}$ soil depth at three different positions in the plastic high tunnel. Similarly, three other sensors were set at $1.5 \mathrm{~m}$ to measure air temperature around tomato plants.

\section{Nitrate concentration in leaf petioles}

The nitrate concentration in the leaf petioles just below the first cluster was determined by means of a reflection photometer RQ flex (Merck Co., Ltd., Darmstadt, Germany). One gram of petioles was macerated with $49 \mathrm{~mL}$ of deionized water (Sakaguchi et al., 2004), and the diluted solution was used for analyses. The leaf petiole samples were collected four times, at 2 , 4,8 , and 10 WAT.

\section{Tomato growth and yield}

The growth index [GI $=$ Plant length $(\mathrm{cm}) \times$ Number of expanded leaves $\times$ Stem diameter $(\mathrm{mm})$ ] (Soma, 1993) was measured using 4 plants in each plot at 7 WAT (July 20), at the beginning of the harvest. The stem diameter was measured $2-3 \mathrm{~cm}$ above the grafted portion, while plant length was measured from the grafted portion to the last expanded leaf of the growing tip, and then the number of completely expanded leaves was collected by counting. Tomato yield was determined using mature tomatoes (red-ripe fruits) harvested from 8 plants per plot every 2-3 days from July 20 to September 25. Fruits with no physiological disorders (cracking, scarring, misshapen fruit, blossom-end rot) and weight over $100 \mathrm{~g}$ were considered marketable fruits.

\section{Statistical analyses}

All tomato and soil characteristics were subjected to statistical analyses using R software, and mean values were evaluated at $5 \%$ probability of significance using Tukey's test. However, for HV, mean values were evaluated using the $t$-test. Values represent the mean of three replications.

\section{Results and Discussion}

\section{Soil and air temperature}

Soil temperature at the root zone $(15 \mathrm{~cm}$ depth $)$ and air temperature were recorded (Table 2). The monthly mean air temperatures varied from $17.8^{\circ} \mathrm{C}$ in May to a maximum of $25.1{ }^{\circ} \mathrm{C}$ in July. However, the monthly mean soil temperatures were more stable, varying from $18.2^{\circ} \mathrm{C}$ in May to $23.5^{\circ} \mathrm{C}$ in August. Generally, temperatures were lower by mid-June and higher in July and August, compared with ordinary years. The soil and air temperature in the plastic high tunnel observed in June, July, and August were suitable for tomato cultivation. The optimum root temperature for mineral uptake and tomato growth is $20^{\circ} \mathrm{C}$ to $30^{\circ} \mathrm{C}$ (Maletta and Janes, 1987; Teasdale and Abdul-Baki, 1995; Tindall et al., 1990), while the optimum air temperature is $18^{\circ} \mathrm{C}$ to $25^{\circ} \mathrm{C}$ (Heuvelink and Dorais, 2005).

\section{Aboveground biomass of hairy vetch}

The HV grew for 64 days, and was mowed in late May. At the mowing time, some plants were flowering. Aboveground biomass weights (dry weight) of $\mathrm{HV}$ at seeding rates of $2 \mathrm{~kg} / 10 \mathrm{a}$ and $5 \mathrm{~kg} / 10$ a were $585 \mathrm{~kg} /$ $10 \mathrm{a}$ and $719 \mathrm{~kg} / 10 \mathrm{a}$, respectively (Table 3). The C:N ratio was lower than 20 which suggested rapid decomposition of organic residues after incorporation into the soil (Brady and Weil, 2007).

\section{Soil carbon and nitrogen}

The HV plots had slightly lower soil inorganic nitrogen (SIN) at week 0 , before transplanting (Fig. 2). The AS10 and HV5 plots exhibited higher SIN $(8.95 \mathrm{mg} /$

Table 2. Mean air and soil temperature in the plastic high tunnel measured during hairy vetch and tomato cultivation in 2015.

\begin{tabular}{lll}
\hline \multirow{2}{*}{ Month } & \multicolumn{2}{c}{ Mean temperature $\left({ }^{\circ} \mathrm{C}\right)$} \\
\cline { 2 - 3 } & Air $^{\mathrm{z}}$ & Soil $^{\mathrm{y}}$ \\
\hline May & 17.8 & 18.2 \\
June & 18.6 & 20.5 \\
July & 25.1 & 22.3 \\
August & 24.2 & 23.5 \\
\hline
\end{tabular}

z Air temperature measured at $1.5 \mathrm{~m}$ height.

${ }^{y}$ Soil temperature measured at $15 \mathrm{~cm}$ depth.

Table 3. Aboveground biomass, carbon, and nitrogen content of hairy vetch.

\begin{tabular}{cccccc}
\hline \hline Hairy vetch & $\begin{array}{c}\text { Fresh weight } \\
(\mathrm{kg} / 10 \mathrm{a})\end{array}$ & $\begin{array}{c}\text { Dry weight } \\
(\mathrm{kg} / 10 \mathrm{a})\end{array}$ & $\begin{array}{c}\text { N content } \\
(\%)\end{array}$ & $\begin{array}{c}\mathrm{N} \text { incorporated } \\
(\mathrm{kg} / 10 \mathrm{a})\end{array}$ & C:N ratio \\
\hline HV2 & 5850 & 585 & 4.3 & 25.2 & 9.6 \\
HV5 & 7190 & 719 & 4.3 & 30.9 & 9.6 \\
$t$-test & $\mathrm{NS}^{\mathrm{x}}$ & $\mathrm{NS}$ & - & $\mathrm{NS}$ & - \\
\hline
\end{tabular}

${ }^{\mathrm{z}} \mathrm{HV} 2$, hairy vetch sowed at a seeding rate of $2 \mathrm{~kg} / 10 \mathrm{a}$; and HV5, hairy vetch sowed at a seeding rate of $5 \mathrm{~kg} / 10 \mathrm{a}$.

${ }^{y}$ Measured just after moving of hairy vetch using a total plot area of $2.4 \mathrm{~m}^{2}$.

${ }^{x}$ NS: not significant. 
$100 \mathrm{~g}$ and $5.44 \mathrm{mg} / 100 \mathrm{~g}$, respectively) compared with other treatments at 2 WAT. However, the SIN in HV2 plots was found to be lower at 2 WAT and then increased until 6 WAT. As expected, ammonium sulfate in the AS10 plots released $\mathrm{N}$ rapidly after application into the soil (Schnier et al., 1987). Its effects were seen until 4 WAT and after that period its SIN levels were comparable to that of the Non HV plots until the end of measurement period. Although all plots showed a decreasing trend, generally SIN in HV plots tended to be higher compared with Non HV and AS10 plots throughout the measurement period. This pattern suggests that although much of its $\mathrm{N}$ was released in the first 4-6 weeks after application, the $\mathrm{N}$ release continued for long period due to decomposition of residues that were initially resistant to microbial degradation (Hue and Silva, 2000). In this regard, Sugihara et al. (2016) reported that HV applied in the previous year contributed slightly to the tomato growth when planted in the following year, especially in the early growth stages. The increased SIN in the first weeks after residue incorporation may indicate that $\mathrm{HV}$ is suitable to be used as a nitrogen source for the early growth stages of tomatoes.

Before tomato cultivation, the total and organic nitro-

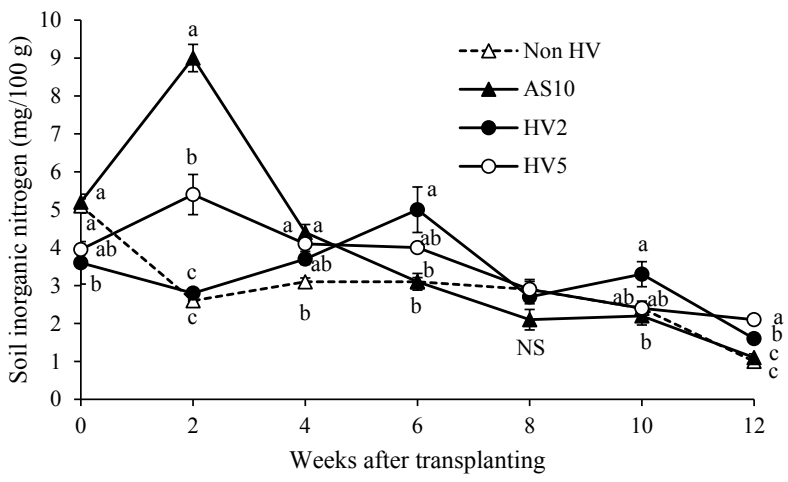

Fig. 2. Inorganic nitrogen concentration in soil during tomato cultivation. Vertical bars represent standards errors $(n=3)$. Means followed by the same letters in each week are not significantly different at $5 \%$, Tukey's test. NS: not significant. gen were higher in Non HV $(285 \mathrm{mg} / 100 \mathrm{~g}$ and $280 \mathrm{mg} /$ $100 \mathrm{~g})$ and AS10 plots $(277 \mathrm{mg} / 100 \mathrm{~g}$ and $272 \mathrm{mg} /$ $100 \mathrm{~g})$ compared with HV2 $(263 \mathrm{mg} / 100 \mathrm{~g}$ and $259 \mathrm{mg} /$ $100 \mathrm{~g})$ and HV5 plots $(251 \mathrm{mg} / 100 \mathrm{~g}$ and $247 \mathrm{mg} / 100 \mathrm{~g})$ (Table 4). However, after tomato cultivation, total and organic nitrogen were higher in $\mathrm{HV}$ and lower in Non $\mathrm{HV}$ and AS10 plots. In comparison with the period before tomato cultivation, soil organic nitrogen increased by $14.3 \%$ and $7.29 \%$ in HV2 and HV5, whereas it decreased by $9.93 \%$ and $18.2 \%$ in AS10 and Non HV, respectively, after tomato cultivation. Similarly, soil carbon increased by $0.34 \%$ and $0.40 \%$ in HV2 and HV5 plots, respectively. In contrast, soil carbon decreased by $0.50 \%$ and $1.37 \%$ in AS10 and Non HV plots, respectively. The increased soil carbon with the HV treatments may have resulted from the incorporation of their residues into the soil (Sainju et al., 2000). Sainju et al. (2015) also reported an increase in soil organic carbon and soil total nitrogen with cover crops (hairy vetch, rye, and hairy vetch + rye) at $0-30 \mathrm{~cm}$ depth under sorghum cultivated as a bioenergy crop. In this study, HV was more effective in increasing soil organic and total nitrogen than soil carbon. These results were consistent with those reported in previous studies (Kuo et al., 1997a, b; Sainju et al., 2003).

\section{Nitrate concentration in leaf petioles}

The nitrate concentration in petiole sap was higher in $\mathrm{HV}$ and AS10 plots compared with Non HV at 4, 8, and 10 WAT (Table 5). No differences among means were observed at 2 WAT. The highest nitrate in petiole sap was observed at 4 WAT in HV5, HV2, and AS10 plots (4775 $\mathrm{mg} \cdot \mathrm{L}^{-1}$ for $\mathrm{HV} 5$, and $4492 \mathrm{mg} \cdot \mathrm{L}^{-1}$ for $\mathrm{HV} 2$ and AS10), and then decreased after 10 WAT. The nitrate concentration in petiole sap is one of the indicators of vegetative growth in tomatoes and is used to determine topdressing time because nitrate concentration in soil is reflected in that of petiole sap (Horimoto et al., 2002). In addition, nitrate concentration reflects the nutrient status of the whole plant and the probable yield of almost all crops (Tanaka, 2003). In this study, nitrate con-

Table 4. Effect of hairy vetch and chemical fertilizer on soil carbon and nitrogen after tomato cultivation.

\begin{tabular}{|c|c|c|c|c|c|c|c|c|c|c|}
\hline \multirow{3}{*}{ Treatments $^{\mathrm{z}}$} & \multicolumn{4}{|c|}{ Before tomato cultivation } & \multicolumn{4}{|c|}{ After tomato cultivation } & \multirow{3}{*}{$\begin{array}{c}\text { Organic } \\
\text { nitrogen } \\
\text { change } \\
(\%)\end{array}$} & \multirow{3}{*}{$\begin{array}{c}\text { Carbon } \\
\text { change }^{\mathrm{w}} \\
(\%)\end{array}$} \\
\hline & \multicolumn{3}{|c|}{ Nitrogen $(\mathrm{mg} / 100 \mathrm{~g})$} & \multirow{2}{*}{$\begin{array}{c}\text { Total carbon } \\
(\%)\end{array}$} & \multicolumn{3}{|c|}{ Nitrogen $(\mathrm{mg} / 100 \mathrm{~g})$} & \multirow{2}{*}{$\begin{array}{c}\text { Total carbon } \\
(\%)\end{array}$} & & \\
\hline & Inorganic & Organic & Total & & Inorganic & Organic & Total & & & \\
\hline Non HV & $5.06(0.19) \mathrm{a}^{\mathrm{y}}$ & $280(4) \mathrm{a}$ & $285(4) \mathrm{a}$ & $6.48(0.17)$ & $1.86(0.08) \mathrm{c}$ & $229(3) \mathrm{c}$ & $231(3) \mathrm{c}$ & $5.11(0.10)$ & -18.2 & -1.37 \\
\hline AS10 & $5.18(0.21) \mathrm{a}$ & $272(3) \mathrm{a}$ & 277 (3) a & $6.07(0.39)$ & $1.82(0.11) \mathrm{c}$ & $245(6) b c$ & $247(6) b c$ & $5.57(0.09)$ & -9.93 & -0.50 \\
\hline HV2 & $3.63(0.56) \mathrm{b}$ & $259(9) \mathrm{ab}$ & $263(9) \mathrm{ab}$ & $5.85(0.16)$ & $2.62(0.08) b$ & $296(7) \mathrm{a}$ & 299 (7) a & $6.19(0.46)$ & 14.3 & 0.34 \\
\hline HV5 & $3.95(0.13) \mathrm{ab}$ & $247(6) b$ & $251(6) b$ & $5.77(0.19)$ & $3.26(0.04) \mathrm{a}$ & $265(2) a b$ & 268 (2) ab & $6.17(0.38)$ & 7.29 & 0.40 \\
\hline
\end{tabular}

z Plots of HV2 and HV5 incorporated hairy vetch sowed at seeding rate of 2 and $5 \mathrm{~kg} / 10$ a, respectively; AS10 was fertilized with $10 \mathrm{~kg}$ N/10 a of ammonium sulfate; and Non HV (control) had no HV and ammonium sulfate.

${ }^{y}$ Means followed by same letters are not significantly different at 5\%, Tukey's test. Brackets indicate standard errors $(n=3)$.

${ }^{x}$ Calculated as follows: (A-B)/B; A-after tomato cultivation, B-before tomato cultivation.

${ }^{\mathrm{w}}$ Difference of soil carbon after and before tomato cultivation. 
Table 5. Nitrate concentration in leaf petioles just below the first cluster during tomato cultivation.

\begin{tabular}{lllll}
\hline \hline & \multicolumn{5}{c}{ Nitrate in petiole sap $\left(\mathrm{mg} \cdot \mathrm{L}^{-1}\right)$} \\
\cline { 2 - 5 } Treatments $^{\mathrm{z}}$ & \multicolumn{4}{c}{ WAT $^{\mathrm{y}}$} \\
\cline { 2 - 5 } & 2 & 4 & 8 & 10 \\
\hline Control & $2867(93)$ & $3417(220) \mathrm{b}^{\mathrm{x}}$ & $2025(75) \mathrm{b}$ & trace $^{\mathrm{w}}$ \\
AS10 & $3000(58)$ & $4492(110) \mathrm{a}$ & $4050(86) \mathrm{a}$ & $2850(29) \mathrm{b}$ \\
HV2 & $2733(130)$ & $4492(156) \mathrm{a}$ & $4283(159) \mathrm{a}$ & $3987(79) \mathrm{a}$ \\
HV5 & $2550(76)$ & $4775(14) \mathrm{a}$ & $3933(72) \mathrm{a}$ & $3525(52) \mathrm{a}$ \\
\hline
\end{tabular}

${ }^{z}$ Plots of HV2 and HV5 incorporated hairy vetch sowed at seeding rates of 2 and $5 \mathrm{~kg} / 10$ a, respectively; AS10 was fertilized with $10 \mathrm{~kg}$ N/10 a of ammonium sulfate; and the Non HV (control) had no HV and ammonium sulfate.

${ }^{y}$ Weeks after transplanting. Brackets indicate the standards errors $(n=3)$.

${ }^{x}$ Means followed by the same letters in each week are not significantly different at $5 \%$, Tukey's test.

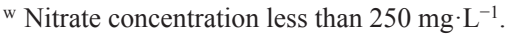

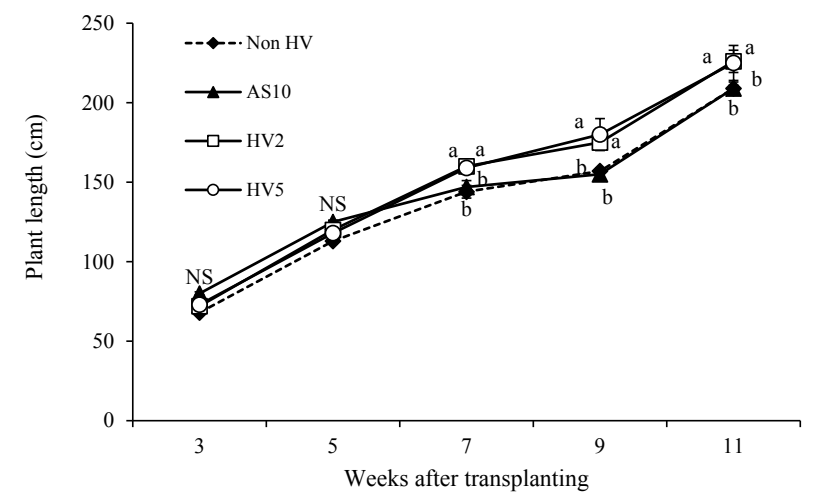

Fig. 3. Effect of hairy vetch and chemical fertilizer on plant length. Vertical bars represent standard errors $(n=3)$. Means followed by the same letters in each week are not significantly different at $5 \%$, Tukey's test. NS: not significant.

centration was close to the minimum level of the optimal nitrate values (4000 to $7000 \mathrm{mg} \cdot \mathrm{L}^{-1}$ ) suggested by Sakaguchi et al. (2004) at 4 to 8 WAT in HV and AS10 plots. Thus, HV and AS10 plots exhibited nitrate values within the proper range for one month. After 8 WAT, nitrate concentration in leaf petiole sap decreased rapidly in AS10, but nitrate sap in HV plots was still close to $4000 \mathrm{mg} \cdot \mathrm{L}^{-1}$. Therefore, $\mathrm{HV}$ may contribute to reduce $\mathrm{N}$ input from chemical fertilizers. Although controlled-release fertilizer (LPS100) was applied to all plots, the nitrate concentration in Non HV plots was below the detection limit of $250 \mathrm{mg} \cdot \mathrm{L}^{-1}$ at $10 \mathrm{WAT}$; in contrast, AS10 plots exhibited a higher nitrate concentration until the end of the measurement period. One possible reason for this discrepancy may be the quick senescence of the lower leaves used for analyses in Non $\mathrm{HV}$ plots, probably due to a lower $\mathrm{N}$ concentration in soil in the first 4 WAT compared with AS10 plots.

\section{Growth index and tomato yield}

Plant length increased vigorously over the period of measurement, especially in HV plots (linear trend) (Fig. 3). However, the effect of the treatments was not significant at 3 to $5 \mathrm{WAT}$, and after that period, plant

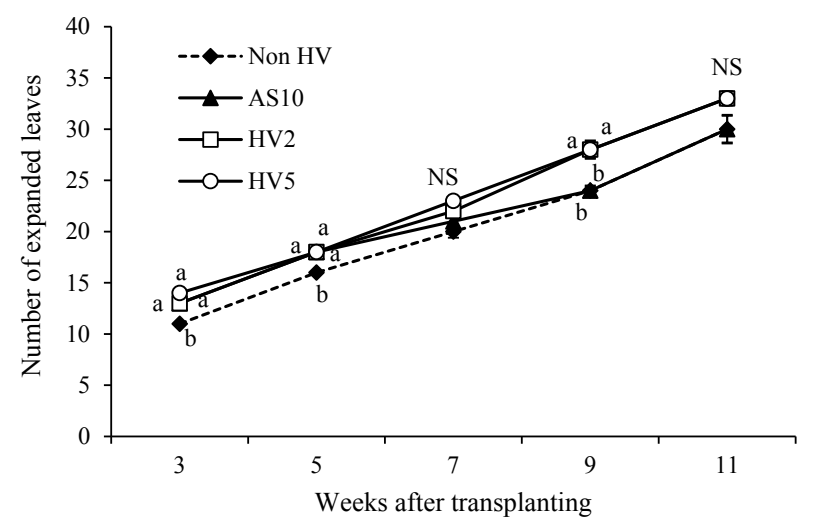

Fig. 4. Effect of hairy vetch and chemical fertilizer on the number of expanded leaves. Vertical bars represent standard errors $(n=$ 3). Means followed by the same letters in each week are not significantly different at $5 \%$, Tukey's test. NS: not significant.

length in HV plots was longer than in AS10 and Non HV plots. Although no significant difference was seen in the initial 5 WAT, plant length tended to be longer in AS10 and HV plots $(125 \mathrm{~cm}$ in AS10, $120 \mathrm{~cm}$ in HV2, $118 \mathrm{~cm}$ in HV5), especially in AS10 than in Non HV plots $(113 \mathrm{~cm})$. Similarly, the number of expanded leaves increased linearly during the measurement period, especially for HV (Fig. 4). There was no significant difference in two sampling dates ( 7 and 11 WAT). Overall, the tomatoes in HV plots displayed a higher number of expanded leaves compared with AS10 and Non HV plots. The effect of HV and AS10 on GI was statistically significant at 7 WAT (July 20) (Table 6). The GI values were 47971 and 46285 in HV2 and HV5, higher than 43397 and 39847 in AS10 and Non HV plots, respectively. It is necessary to ensure a GI of 40000 70000 at the beginning of harvesting time to obtain an average yield (Fujiwara, 2000; Soma, 1993). The GI in HV and AS10 plots was over 40000, and within the recommended range at the beginning of the harvest on July 20. Horimoto et al. (2002) reported similar results. Tomato growing in plots incorporating HV with supplemental N fertilizer showed higher GI (GI over 40000) than non-HV plots with similar supplemental $\mathrm{N}$ fertil- 
Table 6. Effect of hairy vetch and chemical fertilizer on the growth index at 7 WAT, the beginning of the harvest.

\begin{tabular}{ll}
\hline \hline Treatments $^{\mathrm{z}}$ & GI $^{\mathrm{y}}$ \\
\hline Non HV & $39847(386) \mathrm{c}^{\mathrm{x}}$ \\
AS10 & $43397(1303) \mathrm{b}$ \\
HV2 & $47971 \quad(462) \mathrm{a}$ \\
HV5 & $46285(1348) \mathrm{ab}$ \\
\hline
\end{tabular}

z Plots of HV2 and HV5 incorporated hairy vetch sowed at seeding rates of 2 and $5 \mathrm{~kg} / 10$ a, respectively; AS10 was fertilized with $10 \mathrm{~kg}$ N/10 a of ammonium sulfate; and the Non HV (control) had no HV and ammonium sulfate.

y Growth index was calculated as a product of plant length, number of expanded leaves, and stem diameter.

${ }^{x}$ Means followed by the same letters are not significantly different at $5 \%$ Tukey's test. Brackets indicate the standard errors $(n=3)$.

izer at the beginning of the harvest on July 6 . The increased plant length, number of expanded leaves, and stem diameter (data not shown) or GI in HV plots compared with AS10 and Non HV plots suggest that HV-N promotes tomato growth more effectively.

Similar and higher marketable yields were observed in HV plots, $6.87 \mathrm{t} / 10 \mathrm{a}$ in HV2 and $6.91 \mathrm{t} / 10 \mathrm{a}$ in HV5, respectively. The next higher marketable yield was $6.08 \mathrm{t} / 10 \mathrm{a}$ in AS10, and the lowest was observed in Non HV plots, 5.19t/10 a. However, unmarketable yields were not statistically different; $0.67 \mathrm{t} / 10 \mathrm{a}$ in HV2, $0.41 \mathrm{t} / 10 \mathrm{a}$ in HV5, 0.61 t/10 a in AS10, and $0.63 \mathrm{t} / 10 \mathrm{a}$ in Non HV plots (Fig. 5). Increased tomato yield with HV than with no HV was reported in previous studies (Kumar et al., 2005; Sainju et al., 1999; Teasdale and Abdul-Baki, 1997).

The results of the present study clarified that besides the benefits of HV on plant growth and tomato yield previously reported, incorporation of its residues into the soil may increase soil carbon and nitrogen in the short-term. Therefore, HV is an important biological tool for sustainable tomato production systems because it produces a large biomass rich in $\mathrm{N}$ with a low $\mathrm{C}: \mathrm{N}$ ratio that decomposes rapidly and releases $\mathrm{N}$ to tomatoes, thereby reducing the $\mathrm{N}$ fertilizer input. Additionally, it improves yield and soil quality.

In conclusion, the incorporation of $\mathrm{HV}$ residues in soil reduced $\mathrm{N}$ input in $38 \%$, even though good vegetative growth and high marketable yield were obtained. Under plastic high tunnel conditions, HV residues effectively increased soil organic nitrogen, and slightly increased soil carbon. Thus, the research hypotheses were fully supported by the data. HV may be used as an alternative basal $\mathrm{N}$ fertilizer, and the combination of HV with controlled-release fertilizer may be one of the better strategies for fresh-market tomato production in low-input alternative systems because of its agronomic, economic, and environmental merits.

Further research is needed on HV (incorporated and mulched) effects on soil physical and biological proper-

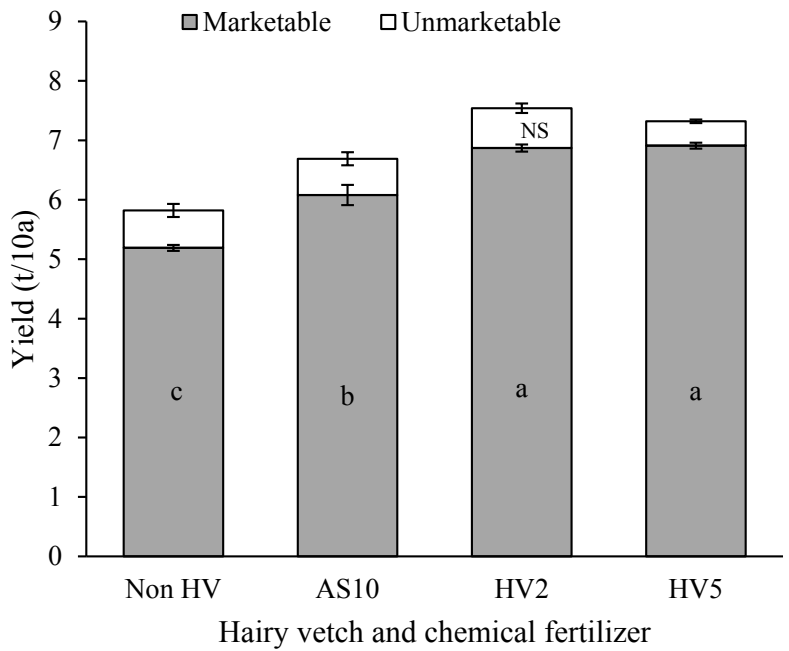

Fig. 5. Effect of hairy vetch and chemical fertilizer on marketable and unmarketable yields. Vertical bars represent standard errors $(\mathrm{n}=3)$. Means followed by the same letters are not significantly different among treatments at 5\%, Tukey's test. NS: not significant.

ties, as well as on nitrate leaching and greenhouse gas emissions in fresh-market tomato production systems. Additionally, research on the $\mathrm{N}$ release pattern from LPS100 in soil and its effectiveness in tomato production is needed because LPS100 was designed for rice production in paddy fields, and also considering the cool climate of Hokkaido, north part of Japan.

\section{Acknowledgements}

The authors thank Mr. Hideki Nakano and Takao Kawai, technicians of the Field Science Center for Northern Biosphere, Hokkaido University, for their great support with the tomato cultivation. We also thank Mr. Daisuke Noguchi, student of the Graduate School of Environmental Science, for his pivotal support in analyses of total nitrogen and carbon.

\section{Literature Cited}

Abdul-Baki, A. A. and J. R. Teasdale. 2007. Sustainable production of fresh-market tomatoes and other summer vegetables with organic mulches. USDA-ARS Farmers' Bull. No. 2280.

Abdul-Baki, A. A., J. R. Teasdale and R. F. Korcak. 1997. Nitrogen requirements of fresh-market tomatoes on hairy vetch and black polyethylene mulch. HortScience 32: 217-221.

Acquaye, S. and K. Inubushi. 2004. Comparative effects of application of coated and non-coated urea in clayey and sandy paddy soil microcosms examined by the ${ }^{15} \mathrm{~N}$ tracer technique. Soil Sci. Plant Nutr. 50: 205-213.

Araki, H. and M. Ito. 1999. Soil properties and vegetable production with organic mulch and no-tillage system. Japan. J. Farm Work Res. 34: 29-37.

Association of agriculture improvement and extension. 2015. Horticultural crops. p. 77-195. In: The Agricultural Administration Department (ed.). Hokkaido fertilizer recommendations (In Japanese). Seibunsha, Sapporo.

Brady, N. C. and R. R. Weil. 2007. The nature and properties of soil. Prentice Hall, New Jersey. 
Fujiwara, S. 2000. Crop nutritional diagnosis. p. 265-278. In: S. Fujiwara, T. Anzai and T. Kato (eds.). Method and application of soil analysis (In Japanese). Noubunkyo, Tokyo.

Hargrove, W. L. 1986. Winter legumes as a nitrogen source for no-till grain sorghum. Agron. J. 78: 70-74.

Heuvelink, E. and M. Dorais. 2005. Crop growth and yield. p. 85-137. In: E. Heuvelink (ed.). Tomatoes. CABI publishing, Wallingford.

Horimoto, S., H. Araki, M. Ishimoto, M. Ito and Y. Fuji. 2002. Growth and yield of tomatoes in hairy vetch-incorporated and-mulched field. Japan. J. Farm Work Res. 37: 231-240.

Hue, N. V. and J. A. Silva. 2000. Organic soil amendments for sustainable agriculture: Organic sources of nitrogen, phosphorus and potassium. p. 133-144. In: J. A. Silva and R. Uchida (eds.). Plant nutrient management in Hawaii's soils: Approaches for tropical and subtropical agriculture. College of tropical agriculture and human resources, University of Hawaii at Manoa, Honolulu.

Ito, T., K. Fujieda, T. Hirose and S. Tachibana. 1990. Sosaiengeigaku (In Japanese). Kawashimashoten, Tokyo.

Kumar, V., A. A. Abdul-Baki, J. D. Anderson and A. K. Mattoo. 2005. Cover crop residues enhance growth, improve yield, and delay leaf senescence in greenhouse-grown tomatoes. HortScience 40: 1307-1311.

Kuo, S. and E. J. Jellum. 2002. Influence of winter cover crop and residue management on soil nitrogen availability and corn yield. Agron. J. 94: 501-508.

Kuo, S., U. M. Sainju and E. J. Jellum. 1997a. Winter cover crop effects on soil organic carbon and carbohydrate. Soil Sci. Soc. Amer. J. 61: 145-152.

Kuo, S., U. M. Sainju and E. J. Jellum. 1997b. Winter cover cropping influence on nitrogen in soil. Soil Sci. Soc. Amer. J. 61: 1392-1399.

Lu, Y. C., K. B. Watkens, J. R. Teasdale and A. A. Abdul-Baki. 2000. Cover crops in sustainable food production. Food Rev. Intl. 16: 121-157.

Maletta, M. and H. W. Janes. 1987. Interrelation of root and shoot temperatures on dry matter accumulation and root growth in tomato seedlings. J. Hort. Sci. 62: 49-54.

Meisinger, J. J., W. L. Hargrove, R. L. Mikkelsen, J. R. Williams and V. W. Benson. 1991. Effects of cover crops on groundwater quality. p. 57-68. In: W. L. Hargrove (ed.). Cover crops for clean water. Soil and Water Conserv. Soc., Ankeny, IA.

Sainju, U. M., H. P. Singh and B. P. Singh. 2015. Cover crop effects on soil carbon and nitrogen under bioenergy sorghum crops. J. Soil Water Conserv. 70: 410-417.
Sainju, U. M., B. P. Singh and W. F. Whitehead. 2000. Cover crops and nitrogen fertilization effects on soil carbon and nitrogen and tomato yield. Can. J. Soil Sci. 80: 523-532.

Sainju, U. M., B. P. Singh and S. Yaffa. 1999. Tomato yield and soil quality as influenced by tillage, cover cropping, and nitrogen fertilization. p. 104-113. In: J. E Hook (ed.). Proceedings of the $22^{\text {nd }}$ annual southern conservation tillage conference for sustainable agriculture. Tifton, GA.

Sainju, U. M., W. Whitehead and B. P. Singh. 2003. Cover crops and nitrogen fertilization effects on soil aggregation and carbon and nitrogen pools. Can. J. Soil Sci. 83: 155-165.

Sakaguchi, M., Y. Hikasa and H. Nakazumi. 2004. Diagnostic technique for nitrogen of summer-autum harvest culture greenhouse tomato. Japan. Soil Sci. Plant Nutr. 75: 29-35.

Schnier, H. F., S. K. De Datta and K. Mengel. 1987. Dynamics of ${ }^{15} \mathrm{~N}$-laveled ammonium sulfate in various inorganic and organic soil fractions of wetland rice soils. Bio. Fertil. Soils 4: $171-177$.

Shoji, S. and H. Kanno. 1994. Use of polyolefin-coated fertilizers for increasing fertilizer efficiency and reducing nitrate leaching and nitrous oxide emissions. Fert. Res. 39: 147-152.

Shoji, S., A. T. Grandeza and K. Kimura. 1991. Stimulation of crop response to polyolefin-coated urea II. Nitrogen uptake by dent corn. Soil Sci. Soc. Amer. J. 55: 1468-1473.

Soma, S. 1993. Growth index. p. 165. Nogyogijutsu taikei. Dojosehi 4 (In Japanese). Nobunkyo, Tokyo.

Sugihara, Y., H. Ueno, T. Hirata and H. Araki. 2013. Uptake and distribution of nitrogen derived from hairy vetch used as a cover crop by tomato plant. J. Japan. Soc. Hort. Sci. 82: 30 38.

Sugihara, Y., H. Ueno, T. Hirata, M. Komatsuzaki and H. Araki. 2016. Contribution of $\mathrm{N}$ derived from a hairy vetch incorporated in the previous year to tomato $\mathrm{N}$ uptake under hairy vetch-tomato rotational cropping system. J. Japan. Soc. Hort. Sci. 85: 217-223.

Tanaka, F. 2003. Plant nutritional diagnosis in Japan, with a special focus on crop quality and the environment. Ibaraki Prefecture, Tsukuba.

Teasdale, J. R. and A. A. Abdul-Baki. 1995. Soil temperature and tomato growth associated with black polyethylene and hairy vetch mulches. J. Amer. Soc. Hort. Sci. 120: 848-853.

Teasdale, J. R. and A. A. Abdul-Baki. 1997. Growth analysis of tomatoes in black polyethylene and hairy vetch production systems. HortScience 32: 659-663.

Tindall, J. A., H. A. Mills and D. E. Radcliffe. 1990. The effect of root zone temperature on nutrient uptake of tomato. J. Plant Nutr. 13: 939-956. 